\title{
'Everyone's Annoyed':
} Leveraging Uncertainty in the Smell of Others

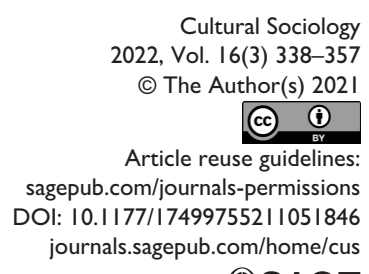

(SAGE

\section{Alison Gerber}

Lund University, Sweden

\begin{abstract}
A growing literature illuminates the limits of claims made on the basis of sensory perception in scientized, rationalized, and bureaucratic contexts. How to understand exceptions to the rule - cases where claims based on sensory experience are taken at face value, even without corroborating evidence? Here, I focus on one such exception, in which citizen complaints about the smell of a small shantytown functioned successfully as both demands and justifications despite a lack of the kinds of instrumentally and technologically enabled corroboration that the literature would suggest are necessary to strengthen such claims. I show how complaints slotted neatly into a specific cultural structure, an olfactory cosmology in which 'bad air' that endangers health can be identified by smell and requires ongoing management and amelioration, and where adherence to hygienic norms is required for full moral citizenship. The case suggests ways that the apparent weaknesses of olfactory claims might allow them to be uniquely weaponized in social and political life, and shows how such claims can exploit shared norms, values, and meanings to enroll others in the demand for action.
\end{abstract}

\section{Keywords}

hygiene education, olfactory claims, public culture, science and technology studies, senses, sensorial citizenship

In 2014 a small shantytown developed in a partially walled vacant lot in a medium-sized city in the south of Sweden. It came to be called the Carefree encampment, after the neighborhood where it was located. At most, about 200 people lived there in around 80 small structures, cars, and mobile homes. The shantytown became local news, then a national story. The media slowly descended on the area, with every major daily and tabloid as well as television and public radio using the Carefree camp as a prism to explore

\section{Corresponding author:}

Alison Gerber, Department of Sociology, Lund University, Box II4, 22100 Lund, Sweden.

Email: alison.gerber@soc.lu.se 
issues like migration, EU regulations, begging bans, and inequality. By the end of that year newspapers and radio programs began to report on complaints that the city was receiving about the settlement, and they noted - mostly in passing - that the majority of complaints were about the smell of the place.

I lived, when the encampment's population was at its highest in 2015, about two blocks from the site, and regularly walked past the shantytown. The square block that housed it had evinced blight for as long as I'd been in the city, the soil poisoned by its industrial history and its absentee landlord showing little interest in its uses by trash dumpers, rough sleepers, or the skateboarders who had built a small concrete park with ramps and a bowl. The summer of 2015 was warm, and we kept our windows open most of the time; we had a balcony where I sat to read. I was confused by the emphasis on smell in the reporting on the shantytown. I experienced no bothersome smells in my home, and on daily walks around the area had never encountered anything noteworthy on the air aside from those scents that had always been there: the smell of fertilizer being produced in the harbor that sometimes settled over the city on cool days; the strong, yeasty, cinnamon-tinged odor of the huge bakery a kilometer away. On sunny days the smell of charcoal grills and excess lighter fluid moved in waves throughout the city, and were especially strong around public parks, where the popularity of the single-use grills sold in every grocery store was evident. But I couldn't smell the encampment.

In November 2015 the city forcefully evicted the residents of the shantytown. Police assembled at four in the morning on a Tuesday to escort the remaining residents and their supporters from the site, and at eight that morning excavators and other heavy machinery began to raze the area.

This article asks: How did a particular stink (or a story about one, at least) become something worth attending to, worrying about, something that drove individuals to demand - and achieve - state action? Why did so many people complain specifically about the smell of the encampment, and why did such complaints seem to work? A growing literature from science and technology studies illuminates the limits of citizen sensation in scientized, rationalized, and bureaucratic contexts; such studies often highlight complainants who struggle to elevate the evidentiary status of their sensory experiences in the face of powerful countervailing forces (Spackman, 2020). Here, I take a different approach, with an inquiry focused on complainants whose claims are taken at face value, to understand the conditions under which citizen sensors' olfactory claims are assigned high evidentiary value despite a lack of corroborating evidence. A broad multidisciplinary literature on odor, aroma, and the senses suggests that it is in othering, boundarydrawing, and racialization processes that we might expect arguments based in smell to carry particular weight (Classen et al., 1994), while a cultural sociological approach leads us to look closely to the cultural structures that might enable a suspension of the usual rules of evidence (Norton, 2014).

In the case considered here, complaints slotted neatly into a specific and wellentrenched set of cultural beliefs about smell: one where 'bad air' that endangers health can be identified by smell and requires ongoing management and amelioration; one where adherence to hygienic norms is required to be considered a good citizen. Olfactory claims - claims based on individual experiences of smell - have unique properties that can allow them to be weaponized in social and political life. Even in the 
absence of independent confirmation - or, perhaps, because of the impossibility of such confirmation - such claims can exploit shared norms, values, and meanings to enroll others in the demand for action. I outline a specific cultural and historical context to show how it allowed particular olfactory claims to leverage the apparent weaknesses of smell as a basis for public debate in order to demand and legitimate state action.

\section{The Power and Limitations of Olfactory Claims}

Those literatures that trace sensory claims-making show that claims built on individual sensory experience are difficult to prosecute when they are not accompanied by measurements legitimated by authority or science. How should exceptions to the rule be understood - cases where claims based on sensory experience are given the benefit of the doubt, even without corroborating evidence? Here, I bring together mulitidisciplinary literatures on olfaction with a special focus on perspectives from science and technology studies, cultural sociology, and cultural anthropology to investigate a case in which unproven olfactory claims were accepted at face value.

Smells are particularly complex sensory objects. Smells and their sensation are uniquely social and context-dependent: scents are simultaneously concrete and ephemeral, both meaning and matter, and olfaction is emerging along with other non-visual senses as particularly generative in a new sociology of sensory perception (e.g. Cerulo, 2018; Friedman, 2016; Schwarz, 2015). European languages have notoriously poor smell vocabularies, and westerners are said generally to pay relatively little attention to smells and to have untrained noses that struggle to discriminate between odors (Jenner, 2000; Kiechle, 2017; O’Meara and Majid, 2016). The experience of olfaction is generally understood to be highly emotion-laden and tightly bound to memory and personal history (Chen and Dalton, 2005; Verbeek and Campen, 2013; Winter, 2016). Of course, smells can spur individuals to immediate action, as when they act to manage and avoid stenches. But given poorly trained noses, impoverished language, and emotion-laden interpretations, scentful experience might seem a poor basis for social action, especially in those contexts that privilege rational public debate. With all of the well-documented barriers to making smell matter, when do claims based on the sense of smell succeed?

A significant literature from science and technology studies focused on sensory claims has shown how hard it can be to enrol others in complaints uncorroborated by 'objective', scientifically authorized documentation. While 'anecdotal evidence' is rarely as easily dismissed as might be imagined (Caverly, 2021; Moore and Stigloe, 2009), a focus on olfactory claims in particular shows how easily complainants are typically disbelieved, dismissed, and delegitimized (Brant, 2008; Reno, 2011; Shapiro, 2015; Spackman and Burlingame, 2018). These findings show that even groups of complainants - whose collectivity should ameliorate some of the apparent weaknesses I have just outlined typically find it hard to promote olfactory claims. The interplay between embodied, emplaced, historicized experts and their decontextualized, 'objective' counterparts implies, of course, that it could be otherwise; some authors have laid out paths toward a more inclusive sensory science (Spackman, 2020). There are of course instances of successful mobilizations around 'big stinks', even those without the kinds of corroborating evidence that would today be widely understood as reliable, authoritative, or legitimate. 
In such cases, some have suggested that mobilization around stenches might, in some cases, rely on nothing more than complainants' imaginations and still be successful when they draw on widely shared cultural meanings (see, for example, Classen, 1992 and the discussion of Morlan, 1950 in Smith, 2006). It seems, though, that most sensory claims fail without technoscientific corroboration. What characterizes those that do gain traction in public debate?

The literatures on sensation and society suggest that it is in othering, boundary-drawing, and racialization processes that we might expect arguments based in smell to carry particular weight. Anthropologists and cultural historians have long considered olfaction to be primarily a social, political, and cultural process (Manalansan, 2006: 50; Reicher et al., 2016). What some scientists consider to be the 'chemical senses', then, should not be conceptualized as straightforward physiological, biological, or psychological processes that can be isolated from emotion, experience, history, or culture (Classen et al., 1994). This does not mean that scentful experience must be treated as idiosyncratic; indeed, culturalist research has illuminated stable patterns that recur across cultural and historical contexts.

While smells are not generally in and of themselves positive or negative, their perception is tightly bound to evaluation (Hinton et al., 2004; McHugh, 2012). It is in research on boundaries and difference that the social experience of scent is most well documented; those considered 'other' are generally perceived to smell badly, while one's own social groups are perceived to smell good or not at all (Cerulo, 2018; Classen, 1993; Reicher et al., 2016). People are quickly habituated to their own smells, and this habituation likely contributes to the othering of those outside of traditional local smellscapes; since in all cultures there is a tendency to perceive unfamiliar scents as unpleasant, the othering power of olfactory experiences is significant (Douglas, 1966; Low, 2005; Porteous, 1985; Synnott, 1991). Anthropologists and cultural historians have shown how crucial olfactory justifications are in constructing and maintaining racialized boundaries (Drobnick, 2006; Eliassi, 2017; Rhys-Taylor, 2014; Smith, 2006; Tullett, 2016), and in the construction of the 'other' across cultural contexts (Hazel, 2014; Holwitt, 2017; Ong, 2003; van Beek, 1992). We might thus expect that olfactory claims could have particular potential in social and political life when they are mobilized around boundaries.

Cultural sociological perspectives promote attention here to the power of cultural structures and to the ways that objects and experiences are made meaningful, especially in relation to the aforementioned processes of evaluation and boundary-drawing. Structuralist approaches and their focus on the interplay between hegemonic cultural codes and individual understandings are particularly influential here (Alexander, 2003; Cerulo, 2018; Lizardo, 2017), especially in the assumptions underlying this article's reliance on archival sources.

This analysis, then, builds most clearly from the findings of historical cultural inquiries, which find that public reason and state action depend far more on the meanings ascribed to objects like smells than on their objective qualities or empirically documented effects and argue that an understanding of such meanings should be central to any inquiry into olfaction and the political aspects of public life (Barnes, 2006; Brant, 2008; Chiang, 2004; Kiechle, 2017; Norton, 2014). As discussed earlier, olfactory claims have particular features that can be imagined as weaknesses: rationalists, for example, 
might argue that smells' apparently close relationship to emotion and memory should disqualify their use as evidence in rational debate, but of course scholars focused on emotion and memory have shown, again and again, how central such 'soft' and 'personal' cultural structures can be to local, national, and international political deliberation and action (Dromi and Türkmen, 2020; Hochschild, 2016; Vinitzky-Seroussi and Teeger, 2010). Cultural sociological approaches confirm the centrality of public codes in meaning-making around fleeting and embodied experience, and suggest that in fact the 'weaknesses' of smells as evidence - their fleeting nature, the difficulty of independent confirmation - could allow claimants to leverage cultural structures that link olfactory experience with urgent public concerns.

Such olfactory claims might be particularly viable when they interact with other categorical distinctions that are both imprecise and deeply felt. The residents of Carefree were typically called, in the media and in everyday conversation, 'EU-migrants', a once innocuous descriptive term that by 2014 had come to imply, in the Swedish context, poverty, homelessness, and social problems (Ramel and Szoppe, 2014), as well as ethnicity. As we will see in this article, some of those who complained to the city about the smell of the encampment presumed that its residents were 'Roma' or 'Gypsies'. Swedish media repeatedly implied that the majority of the encampment's residents were ethnic Roma from Romania and Bulgaria, sometimes treating 'EU-migrants' and 'Roma' as synonyms in their reporting when discussing the Carefree encampment (e.g. Sydsvenskan, 2015b). While in fact Roma identities and labels are complex and often highly problematic (Surdu and Kovats, 2015), in Sweden as elsewhere, 'the Roma' - especially non-Swedish Roma - is a group often enacted and rendered visible and meaningful by bureaucrats, politicians, and experts, rather than by those labeled Roma themselves (Plájás et al., 2019). ${ }^{1}$ A widespread assumption that residents of Carefree must have been Roma, and the historical and cultural baggage that goes with it, that can be seen reflected in the materials discussed in the next section. Despite the lack of attention to the sensorial dimensions of citizenship by contemporary political scientists (Holwitt, 2017; Trnka et al., 2013) there is little reason to imagine that the olfactory experiences and narratives so important to othering processes have been entirely repressed in favor of a politics of rational debate and technocratic action. As discussed earlier, it is in evaluative and boundary-drawing processes that scentful experiences are most strongly felt. We might expect that when such evaluative forces are brought to bear by members of a majority culture against an illdefined, racialized 'other' they might carry particular weight, especially when they draw on widely shared meanings.

This article shows how even unsubstantiated olfactory claims can have real force when they are aligned with cultural structures. I draw on an understanding of olfaction as strongly structured by culture and meaning and cross-disciplinary research on the power of olfactory experience and its influence on in- and out-group dynamics to investigate how olfaction as a social process leaves the realm of individual experience and can be made to generate consequential social change. I ask how individual sensory experiences are turned into convincing arguments, and show how olfactory claims can wield a particular kind of power in the public sphere. 


\section{Materials}

To understand the kinds of cultural affordances that can allow olfactory claims to be taken at face value, this study uses three sets of textual documents to understand the Swedish cultural context, local understandings of the Carefree encampment and its residents, and the destruction of the Carefree encampment: Swedish media reports on the shantytown and its destruction; hygiene textbooks, teachers' newsletters, and other documents pertaining to Swedish hygiene education; and complaints received by the city regarding the Carefree encampment. All translations are my own.

A first dataset consists of Swedish media reports on the shantytown popularly known as the Carefree encampment in Retriever Research / Mediearkivet, a digital archive collecting all major print media as well as public service radio and television in Sweden. My analysis of the articles I collected led me to an interest in cultural norms and values around smells in Sweden. I turned, then, in a second dataset away from individual-level phenomena and towards a body of evidence where norms and values are objectified: the national school system, which explicitly aims to instill national norms and values. ${ }^{2}$ I surveyed the legal documents outlining the Swedish national curricula and read school textbooks and teachers' association newsletters to identify dominant norms and values around hygiene. With the analysis of these texts, I aimed to develop an understanding of a normative Swedish olfactory cosmology: the norms, values, and meanings associated with specific smells in the local context, the ways that sensory models and sensory symbols come together in a particular local worldview (Classen, 1993).

A third body of texts that has informed this study are the complaints that the city received regarding the Carefree encampment in 2014-2015. These complaints were regularly cited in media coverage of the shantytown and controversy over it. Such materials are easily accessible thanks to Sweden's principle of public access to official documents.

This study is based on archival documents and secondary sources; its research questions were prompted by the empirical puzzle discussed in this article - the smell I couldn't smell - but data collection and analysis occurred after the Carefree encampment was destroyed. A significant limitation of this analysis is its minimal engagement with the material and embodied aspects of the case under consideration. The project would have been much richer had, for example, real-time ethnographic and instrumental analysis been undertaken in 2014-2015, as I discuss later.

For analysis of all three bodies of text, I used a modified grounded approach (Becker, 1976; Glaser and Strauss, 1967) centering the constant comparative method (Strauss, 1987). I began with a broad question: What had olfactory complaints meant in the controversy over the Carefree encampment? After confirming that media reports regularly framed the controversy in terms of olfactory complaints, I first worked to understand the cultural context in which such complaints made sense and then compared my burgeoning understanding of the local olfactory cosmology to the actual body of complaints lodged with the city.

\section{Mobilizing Public Culture}

In 2014 the Carefree encampment started to grow in a fenced vacant lot, a well-known local wasteland in a heavy-industry area; a factory had burned there in the early 1900 s 
and tests had shown that the ground was poisoned (Lennartsson, 2015b). As early as 2002 the city had begun fielding complaints about litter and rough sleeping in the lot (Larsson, 2015), and by the middle of 2014 the city had begun to concern itself with the settlement, first asking the property's owners to manage the increasing amounts of litter that residents produced and, with time, shifting to a focus on the health impacts of the settlement on its residents and on the neighborhood at large.

Early media reports on the settlement wrote about the complaints that the city was receiving, and they noted - mostly in passing - that the complaints focused on the smell of the place. The earliest articles quote a city employee who pointed out that since there was no housing in the immediate area the complaints that did come in were from people who biked past the shantytown or who worked in the area: they 'don't like the smell. Everyone's annoyed' (Patzauer, 2014). In late 2014, though, one newspaper claimed in a large-font pull quotation that 'MANY NEARBY RESIDENTS HAVE COMPLAINED' (Forsell, 2014), and from then on the media reported that the issue affected residents in their homes, quickly minimizing the voices of the mainly industrial businesses actually neighboring the site: 'In the last few months fifty or so complaints have been received from residents and restauranteurs in the area, on - among other things - that odors are spreading from trash and smoke throughout the area.' A lawyer working for the city matter-of-factly stated that the smell was a 'nuisance' before assuring city residents that they were not in immediate danger. She outlined health hazards faced by shantytown residents before concluding, 'There is no risk of infection in the surrounding area; it's just that people are disturbed by the smell.' (Lennartsson, 2015c). Throughout 2015 city workers reported and media reports generally featured the running total of complaints received by the city: by April there were 'about 50'; by October, 'more than 90'. (Lennartsson, 2015a, 2015c). The local newspaper ran an editorial in April calling the site an 'unhealthy misery' and citing those 50 complaints and their mention of the smell of the place as evidence when it argued that the shantytown had 'long been an unsustainable situation' (Sydsvenskan, 2015a). By late 2015 nearby residents and their health complaints took center stage in media reports. A representative example comes from the public service broadcaster's report on the 'increasing criticism' the city was receiving regarding the shantytown: while the head of the city's environmental health and safety department acknowledged that litter and rats appeared in some complaints, she led with the smell: 'Lots of the complaints concern people who have felt ill from the smoke or, in some cases, the smell.' The article and radio spot quoted several of the complaints the city had received at length; two of the three that they cited focused on smoke and stink infiltrating homes. (Lennartsson, 2015a). The complaints were reproduced faithfully in the media, and though city workers tried to manage resident's anxieties they, too, contributed to the narrative of the big stink by centering complaints citing smells in their contacts with the media. This despite the mixed results of their own efforts to confirm the smell: city records show staff embarking on olfactory expeditions only to note that any smells were imperceptible until they entered the shantytown itself. The city's instrumental analyses, based on extant air quality monitoring stations, never picked up anything actionable.

\section{Bad Air}

The perennially white walls of Swedish real estate draw on a long history of links between hygienic and moral projects (Berner, 1998; Carlson, 1990; Corbin, 1986); here, 
civility requires olfactory neutrality (Bauman, 2002; Cohen, 1988). To understand the shared beliefs that allowed olfactory claims to make sense in the case of the Carefree encampment, I turn to one proxy for culture - the school system, which both implicitly and explicitly aims to instill national norms, values, and cultural heritage. I draw on Swedish hygiene education to show how a specific olfactory cosmology - the meanings of 'bad air', methods for its management, and the civic and moral duty to manage bad smells - allows smells (or claims about them) to be weaponized against others. National curricula, school textbooks, and teachers' association newsletters display dominant norms and values around smells, their meanings, and their management in a context marked by a tight integration between the state forces of modernization and a focus on hygiene in a top-down civilizing process (Elias, 1978; Frykman, 1994).

Even the earliest hygiene textbooks, which display the themes that would persist for the next 150 years, are clear: (1) Bad air is a health hazard; (2) without specialized tools, the best way to detect this bad air is through its characteristic smells; and (3) bad air is a problem that can and should be solved through hygiene: care of the home and the body (Kastman, 1882; Wallis, 1899). In Sweden, as elsewhere, specific beliefs about 'bad air', its causes, and its consequences, persisted long after miasmatic theories of illness were put to bed (Stenslund, 2015). ${ }^{3}$

Early hygiene textbooks emphasized the importance of clean air for human health and flourishing with a scientistic precision, often operationalizing clean air with mathematical formulae showing the influence of room size and time on indoor oxygen levels. According to these books, inattention to the dangers of bad air would, at the very least, lead to the production through schools of a lazy and poorly educated citizenry; at worst, of course, the sorrow of an early death. And they proclaimed that while chemical scientists could test for the presence of bad air, no technician was necessary; these manuals teach that the 'olfactory sense' could just as well detect its presence (Kastman, 1882: 19). Authors regularly spoke of smells and dangerous substances in the same breath; one could, more often than not, be taken as a sign of the other's presence. 'The air we breathe shall be healthy ... it shall be free of smells and pollutants that can cause harm' (Thunberg, 1912: 64). In these early textbooks, the Swedish reader is told again and again that the olfactory sense can function as the layperson's alert system: where one finds the 'unpleasant smell of perspiration' one is likely to become 'overtaken by nausea' and will fall ill from the combination of heat, still and humid air, and the particulate expressions of unwashed masses; as the nervous system is attacked one will 'fall down, unconscious' (Thunberg, 1912: 86). Bad air - caused usually by some combination of household or workplace uncleanliness and normal bodily processes - was, in these texts, a clear health hazard. These authors showed how scientific measurement could explain why the reader was affected by bad air, but even those readers lacking in specialized tools could detect bad air through its characteristic smells.

Bad air was by the early 1900s well established as a health issue, and it was one that could be managed through care of the built environment and care of the body. Berner's study of household management literature from this time shows how tightly linked the notion of bad air and ill health were in Sweden at the time (Berner, 1998), and early hygiene textbooks devote remarkable page counts to scientistic, specific recommendations for the care of the built environment: regular scouring and even more regular 
airing-out were presented as primary weapons in the battle against the effects of architecture and human activity.

Textbooks provided detailed schedules and procedures for airing-out, and their relationship to oxygen levels, humidity, and smell were extensively discussed. Swedes learned in a discussion of classroom airing-out procedures that they 'have the right to blame ventilation when we, with our nose, sense bad air. What it is in the so-called school air that seems so unpleasant we don't know, but we do know that it has a bad effect on us.' After a discussion of appropriate 'air-space' per student (younger children should receive 15 cubic meters of air per hour, while older children need 18-21 cubic meters per hour) and methods for achieving it, the reader is reminded that while chemical scientists and hygiene researchers provide necessary knowledge, the layperson has all they need to assess ventilation in a given space: 'How can we determine whether, in a particular room, the ventilation is enough? The nose and our judgment are, in most cases, correct.' (Almquist, 1896: 21-32). Attention to ventilation and the practice of airing-out would continue to be central tenets of hygiene instruction for the next 120 years. (Axelsson, 1972; Johnson et al., 1958: 211). Throughout the decades, smell was continually positioned as a relevant signal regarding the health of the built environment, and bad smells were tied to sickness and poor health (Andersson and Wallefors, 1984: 77). But health was not the only reason to keep a clean home and maintain a clean schoolroom; in these texts, a well-ventilated built environment has long been positioned as a sign of respect both for the environment and for others (Janson, 1999: 29), just as care of the body would be.

From the earliest textbooks, care of the body is placed alongside cleaning and ventilation as a primary remedy for bad air. Even the earliest Swedish hygiene textbooks promote bathing at school (Wallis, 1899: 226). Hygiene textbooks over the next decades committed significant space to the technical, architectural, and disciplinary how-to of school baths (e.g. Almquist, 1896), and eventually schools become the 'natural' site of bodily hygiene education (Kunglig Majestät, 1919; Skolöverstyrelsen, 1962: 349). Schools explicitly promoted 'rational' and 'scientific' visions of home and personal hygiene with the hope that children would bring new norms home with them to their unwashed parents.

Mid-century advice collapsed medical and civic admonitions, with a continuing emphasis on smell (not, for example, appearance or dress) as a social threat: 'Dust and dirt constantly adhere to the surface of the skin and any imperfections. All of this provides an excellent home for bacteria . . . dirty and uncared-for skin spreads an unpleasant smell which - even if one is not plagued oneself by it - can be offensive to those nearby' (Tallberg, 1958: 200). Five years later, another textbook claimed: 'Laziness with hygiene causes an unpleasant smell built from sweat and dirt. Often one doesn't recognize it oneself, but those in our surroundings feel it so much more than we do' (Bengtsson and Kallerdahl, 1963: 158). Hygiene textbooks continually highlighted the olfactory sense as offering the primary signal of a poorly maintained, possibly dangerous, and certainly uncourteous body: care of the self was positioned as a way to expand and display consideration for others. Authors suggested that readers 'periodically consider the state of our personal hygiene' and urged them to 'remember that your personal hygiene doesn't just 
concern yourself. It is equally important for the well-being of others' (Axelsson, 1972: 22-23). This passage exemplifies the argument:

We live ever nearer one another - poor hygiene, therefore, has consequences not just for ourselves but also to a great extent for those around us. Deficient hygiene can, among other things, cause infections - through good personal cleanliness such risks can be avoided . . . It has been pointed out many times that hygiene is a form of consideration for others [hygien $\ddot{a} r$ hänsyn]. In our everyday interactions, it is also a necessity . . . In fact, since we are all creatures of habit, the question of hygiene is also a question of proper upbringing. An education in consideration. (Calminder, 1970: 15-28)

Bad air had always been tied in this imaginary to smelly bodies. Those smelly bodies were once seen as the result of natural physical processes whose effluences were easily managed through care of the built environment but became, by the late 20th century, hygienic problems to be solved - not only for one's own health and comfort, but for the health and comfort of one's fellow citizens.

A look at Swedish hygiene education from the past 150 years provides a sense of a specific national olfactory cosmology: one where bad air is constructed as a health hazard, where bad smells are the most reliable signal of the 'bad air' and its dangers for laypeople in their everyday lives. Bad air is seen as easily managed by hygiene practices, so when it appears it is an indication of poor care of the built environment and insufficient care of the body. Care of both the home and the body has by now, in Sweden, been explicitly positioned for decades as necessary for full participation in polite society. Here, it is a civic duty for care for one's own home, workplace, and body - not only on one's own behalf, but also on behalf of one's community. It is the moral duty of each individual to contribute to a healthy society through specific hygienic practices: the smelly home and the stinking body both represent irrefutable evidence of poor citizenship.

\section{The Carefree Encampment}

I lived nearby when the Carefree encampment's population was at its highest and complaints regarding the smell of the place reached their peak, but I couldn't smell it, though I could smell a great many other things. I would of course not assert that the encampment didn't smell - most probably it did, at least sometimes, with any effects probably felt primarily by those who actually lived there. My confusion over the big stink did not really concern any objective presence or absence; rather, with the distance of a relative outsider, ${ }^{4}$ I was interested in the ways that a local community developed an understanding of a smell and its meanings. I wondered why so many people were complaining specifically about the smell of the place - and why such complaints seemed to work.

After the destruction of the encampment, the potency of complaints about the smell of the place - in the media and in everyday interaction - remained with me: conversations featured lips curled in real disgust, the ossification of a narrative insisting that the site had been overwhelmingly stinky. I went to the city to ask to see all of the complaints that had been registered over the years. I was surprised at what I found: a story in which 
bad smells, directly linked to fuzzy concepts of 'fumes' and bad air, were widely understood by complainants and their interlocutors to be indicative of airborne health dangers that required immediate action. Of the complaints received by the city, $45 \%$ based their complaints on smell if I use my strictest definition - using the terms 'smell' and/or 'odor' in their central complaint - and if I loosen my definition to include discussions that include terms like 'fumes' and 'smoke', almost all complaints centered on smell. These were the complaints used to justify concern over the state of the shantytown in the media and by the city workers represented there: complaints that imagined bad air and its associated health concerns hovering continually over a particular city block and regularly transgressing the shantytown's boundaries to endanger the health of the citizenry.

The mildest complainants simply stated that they could no longer air out their homes or enjoy their balconies thanks to smells that were variously described as 'strong', 'dreadful,' 'rank', 'sharp', 'nauseating', and 'nasty' stenches. Recall that in this context, airing-out even in the coldest months represents a basic hygienic practice, and most complainants would likely have agreed with one who wrote that 'ordinary people in their homes must have access to fresh air when they, for natural reasons, open their windows'. A few limited their complaints to the smells that invaded their apartments, but most pointed to one or both of two larger issues: health and environmental effects.

Most of the complainants mentioning smells explicitly linked the smells they claimed to perceive to potential health hazards. A complaint received by telephone was recorded thus: 'The complainant is experiencing a bad smell in their apartment, is afraid of becoming sick, and wonders if we know what the migrants are burning.' Another complainant wrote, 'when they burn their trash it smells terrible and I can guarantee that it damages the lungs. I live [about four blocks away] and some nights my partner and I can't use our balcony.'

Complainants claimed that they experienced 'coughing and nausea', 'asthmatic respiratory disorders', and trouble breathing. Several explained that they were particularly vulnerable to the effects of bad air, with one pointing to diagnoses of asthma and pneumonia and claiming that they both had a particularly pressing need to air out their home and a heightened vulnerability to smells and possible pollutants. One complaint, from a student who parked near the shantytown, claimed to smell trash, burned plastic, and feces before explaining: 'I have a spinal cord injury and thus impaired respiratory function. Which makes me basically have to hold my breath from the time I leave my car until I get into the school, since it otherwise feels like my lungs are filled with poisonous fumes.' The student did not claim that they experienced any health effects from the smells per se - but centered their vulnerability in their complaint. Another complainant focused on the vulnerability of small children, demanding that the city prove, with facts and measurements, that no harm would come to children in the area from the 'fumes and smells', pointing to their immature immune systems to claim the need for urgent action.

Many complaints claimed to fear for the health of the public; these complaints were concerned about the potential reach of the 'fumes' released by shantytown residents' fires and the 'hotbed of infection and bacteria' that they argued the place represented. They imagined numerous vectors of contagion: birds landing near feces, rats, the wind - and freely blended concerns about fumes and human waste: 
Like most already know, the squatters are burning all kinds of refuse so all kinds of contaminated poison gases are spreading throughout the city . . . the health of all of us hangs in the balance. City residents are at risk of an epidemic thanks to particulate bacteria from the beggars' fecal matter as it spreads on the wind that each and every one of us breathes into our lungs.

Complaints with a public health focus took a more aggressive tone towards public workers, and demanded action from the city with more vigor: 'It won't take long before some epidemic begins, all because the municipality doesn't dare to hit the brakes.'

Environmental concerns were also commonly cited in complaints; a bad smell was often presented as proof of an environmental hazard. "They're burning in their "houses" and it smells awful. They must be burning everything possible, which is clearly inappropriate and environmentally harmful.' 'Often their fires produce a ton of thick, grey, bad-smelling smoke. It's definitely not good for the environment!!' Concern for the environment was often connected in these complaints with concern that local regulations were not being followed:

What they're burning I don't know but it smells terrible in the car [when I drive by], how do you think it smells outside? From an environmental point of view, living in a 'shantytown', their habits of littering and burning things - it's something that I as a Swedish citizen would never consider. Using your fireplace at home is regulated, but what is the case here? Fire wherever, using whatever you want? Just because you're an immigrant doesn't mean that it's legal and permitted to do whatever you want.

Such complaints pointed to laws and regulations that they believed shantytown residents to be breaking. 'It's of course illegal to build fires in urban areas, so why aren't they being stopped? Maybe the rules don't apply to them?' Two such rule-focused complaints obliquely compared the residents of the shantytown to animals: 'I have a dog and pick up after her while these people poop and pee "in the open" and leave clear traces of themselves - a totally absurd situation.' 'I have two dogs . . . Many times I've seen people openly sitting and pooping and peeing in there . . . it feels totally absurd that I'm walking on the other side of the fence and picking up my dogs' poop!' And both of the lightly veiled threats against the shantytown residents that I found in the complaints focused on law and order, with one claiming to be 'worried that people will take things into their own hands because they're so angry that the shantytown is allowed to stand even though it violates the law.'

The management of bad air is widely understood to be a basic requirement of civility in this context, and the reader will already have seen in many of the foregoing quotations clear lines drawn between the people that complainants called 'us' - the 'legitimate' residents of the city, of Sweden - and 'them', a people those complainants often rendered in explicitly racist and xenophobic language. The people the complaints focused on were variously termed 'EU-migrants' (the then-current preferred term, often rendered by complainants in sarcastic quotation marks), 'zigenare', 'Roma', and 'gypsies'; sometimes 'beggars' or 'squatters'. Complainants contrasted such groups with their own: 'normal Swedish citizens', 'regular people in their homes', 'regular working people', 'everyday Swedish citizens', 'taxpayers and citizens'. Reading the complaints, I was continually taken aback at both the explicit and implicit content of those that made clear 'us'/'them' 
distinctions, like this complainant who claimed their legitimacy as an 'orderly normal Swedish citizen' before launching into their grievance:

They should be thankful they haven't been shot . . Here we have rules, and we Swedes follow them; these damned parasites on the Swedish society should fucking do what they're told . . . They only create problems for us honest Swedes. Dirty mattresses, rubbish, pissing, filthy all around where they 'live'. Is this really the kind of foreigner we ordinary Swedish people want? ... Every day the unhygienic problems grow and grow and smell more . . Hotbeds of bacteria are beginning to spread from all the excrement and urine the disrespectful residents leave. They don't even understand how normal people live. All of their stuff lying around everywhere is full of mold, infectious materials, bacteria, things like that. Do you understand that if this stuff isn't removed immediately and decontaminated, this shit will spread through the city? The entire city's population could get long-term illnesses and allergies just because you damned authorities can't get your thumbs out of your asses.

The complaints the city received vary along two major dimensions: some are concerned with public health while others focus on the environment; some simply report an unusual smell they find troublesome while others - like this one - wallow in open racism and xenophobia. By continually claiming and calling attention to their own status as 'Swedes' and 'citizens', 'normal' 'everyday' people, complainants continually asserted their ingroup status and linked their preferences with a state-supported majority culture that, as we have seen, is enshrined in generations of textbooks and transmitted to all through the compulsory school system. The obvious power differential between those who claimed to smell terrible smells and the residents of Carefree, whose voices were rarely represented in the public discourse, was significant.

In the end, hygiene issues - lack of access to water and sanitation facilities - were key to the destruction of the encampment (Davis and Ryan, 2017). ${ }^{5}$ It was the 'big stink' story that hovered at the center of the complaints the city received; that narrative that city workers pointed to, noses wrinkled in disgust, in their contacts with the media; that story that now sits at the center of an already-ossified narrative of the place and its destruction. As I write this, more than five years later, the site looks almost exactly as it did in late 2015: fences surround a weed-and-litter-covered lot. People sometimes sleep there, but avoid building any structures. On the map, it is a grey, unmarked absence. The complaints the city received slotted nicely into a specific cultural structure: one where the 'bad air' that endangers health can be identified by smell and requires ongoing management and amelioration; one where adherence to hygienic norms is required for full moral citizenship (Schinkel, 2010; Synnott, 1991). Smells were the stated cause for most of the complaints the city received; that these complaints were taken seriously despite the inability of complainants to instrumentally document their experiences or of city workers to confirm them speaks to the power of the olfactory claim in this context.

\section{Conclusion}

Previous research has shown how easily governmental, bureaucratic, and scientific actors can dismiss even well-documented claims when they are based on the 'anecdotal 
evidence' of citizen sensation. But olfactory claims do not always fail to gain traction. When are they likely to succeed? Here, I look to a case in which olfactory claims appear to have been taken at face value by many who encountered them. The claims were reproduced in the media as evidence of a problem, and were cited by officials in justifying their actions. Olfactory claims in this case successfully functioned both as public demands and public justifications - this despite a dearth of the kinds of enumeration and technoscientific corroboration that we would expect to be necessary to strengthen such claims.

While we might expect the uncertainties associated with individual olfactory claims would weaken their evidentiary value, might it be possible that in some contexts such uncertainties are exactly the features that give such claims their power? Much of the previous literature takes as its focus the underdog - claimants, usually falling somewhere between sympathetic and righteous, who achieve limited success in their interactions with capital, state power, or medical authorities. These projects typically involve two underlying assumptions: first, that claimants' bodies are (at least potentially) more sensitive than scientific instruments; second, that their sensory perceptions and interpretations of those perceptions are reliable. In this article I have taken the opposite tack: I began with a small puzzle, a smell that I couldn't smell, and tried to understand how olfactory claims that ranged from impossible-to-verify to deeply objectionable managed to gain traction in public debate. An analysis focused on claimants' experiences rather than the public debate would certainly have asked different questions and led to different conclusions. Here, analysis of media coverage of the shantytown, its residents, and their eventual eviction confirmed the centrality of a 'big stink' narrative, while a historical analysis of hygiene education in Sweden sketched the outlines of a local cultural structure that centers the smell of 'bad air' as an indicator of health hazards and promotes hygiene as a contribution to society. Finally, an analysis of all complaints received by the city regarding the shantytown showed how deeply intertwined the meanings of bad smells, health hazards, and moral citizenship were in this context and how that cultural structure was deployed together with moral arguments about the importance of rule-following in a locally specific process of othering by complainants who claimed their power through continually evoking membership in a majority culture.

This analysis supports the adoption of a model such as that offered by Schwarz (2015) for the analysis of the experience and evaluation of sensory phenomena, in which discourses and cultural structures interact with embodied experiences and boundary-making processes. An extension of said model in the olfactory realm would include further engagement with the molecular, physical, and biological qualities of smells, as well as longitudinal ethnographic engagement. Agapakis and Tolaas (2012), Liboiron (2016), Shapiro (2015), and Spackman (2020) offer models for the incorporation of materiality into analyses such as this one, and further research would benefit from the incorporation of instrumental measurement whenever possible; we should not shy away from the possibilities that come with theoretically saturated comparative work that takes the kinds of scientistic measurements and statements of fact that carry weight in public deliberations seriously. While this study has focused specifically on public culture, it would have been much richer had it included ethnographic data - local observations over several years and interviews with residents of Carefree, complainants, city workers, and others. Such data 
would allow the analyst to answer the kinds of questions that cannot be addressed here - to tease apart the mechanisms of meaning construction (Lizardo, 2017; Norton, 2018); to understand the influence of contingent experiences of resonance on framings that simply 'make sense' to particular groups (McDonnell et al., 2017; Rawlings and Childress, 2019). This analysis rests squarely in the realm of public culture, but to take smell seriously in public life a multifaceted, multimethod approach will be necessary.

In the case considered here, specific features of the local olfactory cosmology allowed complaints about smells to be understood as legitimate concerns regarding public and environmental health hazards, and were used by the local government and the media to justify a mass eviction and the destruction of an informal housing settlement. The near impossibility of independent confirmation meant that complainants enjoyed enormous latitude in setting the terms of debate. The case at hand shows that evidentiary uncertainty, when coupled with power and buttressed by culture, can be a strength in claimsmaking processes. Olfactory claims have unique properties when deployed for a purpose, since even in the absence of independent confirmation - or, perhaps, because of the impossibility of such confirmation - such claims can exploit broadly shared norms, values, and meanings to enroll others in the demand for action.

\section{Acknowledgements}

Since this work has knocked around a while, I'm certainly forgetting folks, to whom I apologize. Special thanks to Dalia Abdelhady, Clayton Childress, Nicola Ens, Erik Hannerz, Mai Lundemark, Rhiannon Pugh, Dominic Power, editor Marcus Morgan, and Cultural Sociology's anonymous reviewers.

\section{Declaration of Conflicting Interests}

The author declared no potential conflicts of interest with respect to the research, authorship, and/ or publication of this article.

\section{Funding}

The author disclosed receipt of the following financial support for the research, authorship, and/or publication of this article: This work was supported in part by a Swedish Research Council framework grant on Culture, Creativity, and Economy.

\section{Notes}

1. Evidence to this effect - that it is 'public perception and expert assertions' that make up 'the Roma' (Surdu and Kovats, 2015: 9) - are not hard to find, as in this account focused on Swedish violations of vulnerable EU migrants' human rights: 'records of official communications, reports from the media, and accounts from eyewitnesses confirm the Roma identity of the inhabitants of the affected sites. Among the official records analyzed for this study are the notes of officials discussing the evictions, which include the following comments: 'we have problems with various bums/Roma', 'there were sleeping Roma in the cars', 'it is very hard for us to determine the identity of EU-emigrants', and 'we have issue in an area where there are Romanians' (Davis and Ryan, 2017: 62). As an 'eyewitness' to the Carefree encampment myself, I would not personally take the evidence cited here as confirmation of its inhabitants' Roma ethnic identity. I met some who self-identified as Romanian in casual interaction, but 
none who volunteered Roma identity - but I did no quantitative survey of residents, and there is ample evidence that capturing an 'objective' census of Roma in the encampment would have been problematic at best. These authors citing city officials' statements do capture the fact that it is usually expert and public judgments that matter in the long, well-documented history of discrimination, hate, and violence against those who identify or are identified as Roma across Europe (van Baar, 2017, Yıldız and De Genova, 2018). Sweden, where an illegal police database of people believed to be Roma that included small children was recently uncovered (Orrenius, 2013), has unfortunately never been an exception to this rule (Montesino and $\mathrm{Al}$ Fakir, 2015; Nyhlén, 2020; Teodorescu and Molina, 2020). In Sweden as elsewhere, benevolent state violence has often been premised on the protection of those officially labeled Roma from their own 'unsanitary' living conditions (Barker, 2017; Hansson and Mitchell, 2018), while interindividual violence and hate crimes bear more obvious traces of a racialization of poverty and difference (Fox et al., 2012; Plájás et al., 2019, van Baar, 2018).

2. As the Swedish Ministry of Education and Science writes:

The school has the important task of imparting, instilling and forming in pupils those values on which our society is based ... Education and upbringing involve passing on a cultural heritage - values, traditions, language, knowledge - from one generation to the next . . The school shall actively and consciously influence and stimulate pupils into embracing the common values of our society and express these in practical daily action. (Swedish Ministry of Education and Science, 1994: LPO 94: 6-8, 14)

The school system is not here considered to have a straightforwardly causal role in the development of these norms and values; rather, it reflects elite and normative values while reinforcing and extending them.

3. The early obsession with 'bad air' was not out of place at a time when the last miasmatic theories of disease were very slowly being replaced by germ theories. Graninger showed how slowly bacteriological theories replaced earlier understandings of disease in the Swedish context (Graninger, 1997), and this was not simply a local process: Barnes showed in his study of two great stinks in Paris how the core assumptions of miasmatic theories persisted well after the establishment of bacteriological understandings of disease, in part through their influence on whether and how new ideas were taken up both in and outside of the scientific and medical communities (Barnes, 2006).

4. I am from the USA, and lived there for most of my life. I lived in Sweden from 2003 to 2008, moved back to the USA from 2008 to 2015, and returned to live in Sweden in 2015.

5. Alternative rationales for the eviction of Carefree's residents, including adherence to laws on squatting and migration, were floated in Malmö in 2014 and early 2015 with no success, though in mid-2015 a new national 'zero tolerance' policy that in effect reconceptualized evictions as public-order focused 'removals' might have made new such efforts more likely to succeed (Barker, 2017; Nyhlén, 2020). Had the city's environmental health and safety argument not held up to legal scrutiny (or the court of public opinion) another strategy would likely have been forthcoming: the shantytown was located near the heart of the city's largest and most centrally located development project, where new housing for 5000 residents is being built. But the economics of real estate can explain little about the particular form that complaints and eventual government action took in this case.

\section{References}

Agapakis CM and Tolaas S (2012) Smelling in multiple dimensions. Current Opinion in Chemical Biology 16(5): 569-575. 
Alexander JC (2003) The Meanings of Social Life: A Cultural Sociology. New York: Oxford University Press.

Almquist E (1896) Lärobok i Skolhygien För Seminarier, Skolråd, Lärare m. Fl. Stockholm: PA Norstedt \& Söners Förlag.

Andersson U-B and Wallefors B-M (1984) Hemkunskap För Högstadiet. Stockholm: Natur och Kultur.

Axelsson M (1972) Vårda Sin Hälsa: Förebyggande- Akut- Och Hemsjukvård. Stockholm: LTs Förlag.

Barker V (2017) Nordic vagabonds: The Roma and the logic of benevolent violence in the Swedish welfare state. European Journal of Criminology 14(1): 120-139.

Barnes DS (2006) The Great Stink of Paris and the Nineteenth-Century Struggle Against Filth and Germs. Baltimore, MD: Johns Hopkins University Press.

Bauman Z (2002) The sweet scent of decomposition. In: Rojek C and Turner B (eds) Forget Baudrillard? Abingdon: Routledge, 22-46.

Becker HS (1976) Sociological Work: Method and Substance. New Brunswick, NJ: Transaction Publishers.

Bengtsson A and Kallerdahl K (1963) Hemkunskap i 50 Lektioner. Lund: Gleerups.

Berner B (1998) The meaning of cleaning: The creation of harmony and hygiene in the home. History and Technology 14(4): 313-352.

Brant C (2008) Scenting a subject: Odour poetics and the politics of space. Ethnos 73(4): 544-563.

Calminder B (1970) Renare i Skinnet. In: Tidholm K (ed.) 10 Gånger Renare: En bok om hygien för nutidsmänniskan. Uppsala: Husmodersförbundet Hem och Samhälle och Hygienbyrån, $14-28$.

Carlson AC (1990) The Swedish Experiment in Family Politics: The Myrdals and the Interwar Population Crisis. New Brunswick, NJ: Transaction.

Caverly NL (2021) Sensing others: Empty buildings and sensory worlds in Detroit: Environment and Planning C: Politics and Space 39(6): 1079-1096. DOI: 10.1177/2399654419858368.

Cerulo KA (2018) Scents and sensibility: Olfaction, sense-making, and meaning attribution. American Sociological Review 83(2): 361-389.

Chen D and Dalton P (2005) The effect of emotion and personality on olfactory perception. Chemical Senses 30(4): 345-351.

Chiang CY (2004) Monterey-by-the-smell. Pacific Historical Review 73(2): 183-214.

Classen C (1992) The odor of the other: Olfactory symbolism and cultural categories. Ethos 20(2): $133-166$.

Classen C (1993) Worlds of Sense: Exploring the Senses in History and across Cultures. London and New York: Routledge.

Classen C, Howes D and Synnott A (1994) Aroma: The Cultural History of Smell. London and New York: Routledge.

Cohen E (1988) The broken cycle: Smell in a Bangkok soi (lane). Ethnos 53(1-2): 37-49.

Corbin A (1986) The Foul and the Fragrant: Odor and the French Social Imagination. Cambridge, MA: Harvard University Press.

Davis MS and Ryan N (2017) Inconvenient human rights: Water and sanitation in Sweden's informal Roma settlements. Health and Human Rights Journal 19(2): 61-72.

Douglas M (1966) Purity and Danger. London: Routledge.

Drobnick J (2006) The Smell Culture Reader. Oxford and New York: Berg.

Dromi SM and Türkmen G (2020) What does trauma have to do with politics? Cultural trauma and the displaced founding political elites of Israel and Turkey. The Sociological Quarterly 61(1): 22-41.

Elias N (1978) The Civilizing Process. Oxford: Blackwell. 
Eliassi B (2017) Conceptions of immigrant integration and racism among social workers in Sweden. Journal of Progressive Human Services 28(1): 6-35.

Forsell M (2014) Moment 22 För Tältläger. Skånska Dagbladet, 21 October, A7.

Fox JE, Moroşanu L and Szilassy E (2012) The racialization of the new European migration to the UK. Sociology 46(4): 680-695.

Friedman AM (2016) Perceptual construction: Rereading the social construction of reality through the sociology of the senses. Cultural Sociology 10(1): 77-92.

Frykman J (1994) On the move: The struggle for the body in Sweden in the 1930s. In: Seremetakis CN (ed.) The Senses Still: Perception and Memory as Material Culture in Modernity. Boulder, CO: Westview Press, 63-85.

Glaser BG and Strauss AL (1967) The Discovery of Grounded Theory: Strategies for Qualitative Research. Chicago, IL: Aldine Publishing.

Graninger U (1997) Från osynligt till synligt: bakteriologins etablering $i$ sekelskiftets svenska medicin. Stockholm: Carlsson.

Hansson E and Mitchell D (2018) The exceptional state of 'Roma beggars' in Sweden. European Journal of Homelessness 12(2): 15-40.

Hazel YP (2014) Sensing difference: Whiteness, national identity, and belonging in the Dominican Republic. Transforming Anthropology 22(2): 78-91.

Hinton D, Pich V, Chhean D, et al. (2004) Olfactory-triggered panic attacks among Khmer refugees: A contextual approach. Transcultural Psychiatry 41(2): 155-199.

Hochschild AR (2016) Strangers in Their Own Land: Anger and Mourning on the American Right. New York: New Press.

Holwitt P (2017) Strange food, strange smells: Vegetarianism and sensorial citizenship in Mumbai's redeveloped enclaves. Contemporary South Asia 25(4): 333-346.

Janson B (1999) Rent hus i fartfylld final. Hushållsläraren (4): 28-29.

Jenner MSR (2000) Civilization and deodorization? Smell in early modern English culture. In: Burke P, Harrison B and Slack P (eds) Civil Histories: Essays Presented to Sir Keith Thomas. Oxford: Oxford University Press, 128-145.

Johnson E, Carpenter K and Bolin I (1958) Födan - Hemmet - Ekonomin: Kokbok För Skola Och Hem (20th edn). Göteborg: Gumperts Förlag AB.

Kastman C (1882) Skolan Och Hemmet: Samling Af Uppsatser Rörande Uppfostran Och Undervisning (2nd edn). Stockholm: PA Norstedt \& Söners Förlag.

Kiechle MA (2017) Smell Detectives: An Olfactory History of Nineteenth-Century Urban America. Seattle: University of Washington Press.

Kunglig Majestät (1919) Undervisningsplan För Rikets Folkskolor Den 31 Oktober 1919. Stockholm: PA Norstedt \& Söners Förlag.

Larsson L (2015) Städslut för omstridd tomt. Skånska Dagbladet, 6, 7 November.

Lennartsson D (2015a) Allt hårdare kritik mot kåkstaden i Malmö. Sveriges Radio, 12 October.

Lennartsson D (2015b) Efter Lägret - Nu Ska Bostäder Komma - P4 Malmöhus / Sveriges Radio. P4 Malmöhus / Sveriges Radio, 1 December.

Lennartsson D (2015c) Ny plan ska få bort Sorgenfriläger. Sveriges Radio, 15 April.

Liboiron M (2016) Redefining pollution and action: The matter of plastics. Journal of Material Culture 21(1): 87-110.

Lizardo O (2017) Improving cultural analysis: Considering personal culture in its declarative and nondeclarative modes. American Sociological Review 82(1): 88-115.

Low KEY (2005) Ruminations on smell as a sociocultural phenomenon. Current Sociology 53(3): $397-417$.

Manalansan MF (2006) Immigrant lives and the politics of olfaction in the global city. In: Drobnick J (ed.) The Smell Culture Reader. Oxford and New York: Berg, 41-52. 
McDonnell TE, Bail CA and Tavory I (2017) A theory of resonance. Sociological Theory 35(1): $1-14$.

McHugh J (2012) Sandalwood and Carrion: Smell in Indian Religion and Culture (1st edn). New York: Oxford University Press.

Montesino N and Al Fakir IO (2015) The prolonged inclusion of Roma groups in Swedish society. Social Inclusion 3(5): 126-136.

Moore A and Stilgoe J (2009) Experts and anecdotes: The role of 'anecdotal evidence' in public scientific controversies. Science, Technology, \& Human Values 34(5): 654-677.

Morlan GK (1950) An experiment on the identification of body odor. The Pedagogical Seminary and Journal of Genetic Psychology 77(2): 257-265.

Norton M (2014) Mechanisms and meaning structures. Sociological Theory 32(2): 162-187.

Norton M (2018) Meaning on the move: Synthesizing cognitive and systems concepts of culture. American Journal of Cultural Sociology 7(1):1-28. DOI: 10.1057/s41290-017-0055-5.

Nyhlén S (2020) 'We should call them our friends' - Negotiations on welfare and social security entitlements for displaced EU citizens in Sweden. In: Mantu S, Minderhoud P and Guild E (eds) EU Citizenship and Free Movement Rights. Leiden: Brill Nijhoff, 215-239.

O'Meara C and Majid A (2016) How changing lifestyles impact seri smellscapes and smell language. Anthropological Linguistics 58(2): 107-131. DOI: 10.1353/anl.2016.0024.

Ong A (2003) Buddha is Hiding: Refugees, Citizenship, the New America. Berkeley: University of California Press.

Orrenius N (2013) Över tusen barn med i olaglig kartläggning. Dagens Nyheter, 23 September.

Patzauer J (2014) EU-migranter riskerar att vräkas. Skånes Fria Tidning. Available at: http://www. skanesfria.se/artikel/115452 (accessed 31 October 2021).

Plájás IZ, M'charek A and van Baar H (2019) Knowing 'the Roma': Visual technologies of sorting populations and the policing of mobility in Europe. Environment and Planning D: Society and Space 37(4): 589-605.

Porteous JD (1985) Smellscape. Progress in Physical Geography 9(3): 356-378.

Ramel F and Szoppe A (2014) EU-migrant ett problematiskt begrepp. Radio Sweden på svenska. Available at: http://sverigesradio.se/artikel/5915740 (accessed 9 July 2021).

Rawlings CM and Childress C (2019) Emergent meanings: Reconciling dispositional and situational accounts of meaning-making from cultural objects. American Journal of Sociology 124(6): 1763-1809.

Reicher SD, Templeton A, Neville F, et al. (2016) Core disgust is attenuated by ingroup relations. Proceedings of the National Academy of Sciences 113(10): 2631-2635.

Reno J (2011) Beyond risk: Emplacement and the production of environmental evidence. American Ethnologist 38(3): 516-530.

Rhys-Taylor A (2014) Urban sensations: A retrospective of multisensory drift. In: Howes D (ed.) A Cultural History of the Senses in the Modern Age. London: Bloomsbury, 55-76.

Schinkel W (2010) The virtualization of citizenship. Critical Sociology 36(2): 265-283.

Schwarz O (2015) The sound of stigmatization: Sonic habitus, sonic styles, and boundary work in an urban slum. American Journal of Sociology 121(1): 205-242.

Shapiro N (2015) Attuning to the chemosphere: Domestic formaldehyde, bodily reasoning, and the chemical sublime. Cultural Anthropology 30(3): 368-393.

Skolöverstyrelsen (1962) Läroplan För Grundskolan (Kungl. Skolöverstyrelsens Skriftserie 60) (2nd edn). Stockholm: SÖ-förlaget.

Smith MM (2006) How Race is Made: Slavery, Segregation, and the Senses. Chapel Hill: University of North Carolina Press.

Spackman C (2020) In smell's shadow: Materials and politics at the edge of perception: Social Studies of Science 50(3): 418-439. DOI: 10.1177/0306312720918946. 
Spackman C and Burlingame GA (2018) Sensory politics: The tug-of-war between potability and palatability in municipal water production. Social Studies of Science 48(3): 350-371.

Stenslund A (2015) A whiff of nothing: The atmospheric absence of smell. The Senses and Society 10(3): 341-360.

Strauss AL (1987) Qualitative Analysis for Social Scientists. Cambridge: Cambridge University Press.

Surdu M and Kovats M (2015) Roma identity as an expert-political construction. Social Inclusion 3(5): $5-18$.

Swedish Ministry of Education and Science (1994) 1994 Curriculum for Compulsory Schools: Lpo 94. Stockholm: Utbildningsdep.

Sydsvenskan (2015a) Hälsofarlig Misär. Sydsvenskan, 23 April.

Sydsvenskan (2015b) Lagen Ska Gälla, Lika För Alla. Även Tiggare. Sydsvenskan, 2 November, 2.

Synnott A (1991) A sociology of smell. Canadian Review of Sociology/Revue Canadienne de Sociologie 28(4): 437-459.

Tallberg A (1958) Hälsa Och Sjukdom i Hemmet. Stockholm: LTs Förlag.

Teodorescu D and Molina I (2020) Roma street-workers in Uppsala: Racialised poverty and super precarious housing conditions in Romania and Sweden. International Journal of Housing Policy 21(3): 401-422.

Thunberg T (1912) Hälsolärans Grunder. Uppsala: Sverges Lärares Nykterhetsförbund / J.A. Lindblads Förlag.

Trnka S, Dureau C and Park J (2013) Introduction: Senses and citizenships. In: Trnka S, Dureau $\mathrm{C}$ and Park J (eds) Senses and Citizenships: Embodying Political Life. London: Routledge, $1-32$.

Tullett W (2016) Grease and sweat: Race and smell in eighteenth-century English culture. Cultural and Social History 13(3): 307-322.

Van Baar H (2017) Evictability and the biopolitical bordering of Europe. Antipode 49(1): 212-230.

Van Baar H (2018) Contained mobility and the racialization of poverty in Europe: The Roma at the development-security nexus. Social Identities 24(4): 442-458.

Van Beek WEA (1992) The dirty smith: Smell as a social frontier among the Kapsiki/Higi of north Cameroon and north-eastern Nigeria. Africa: Journal of the International African Institute 62(1): $38-58$.

Verbeek C and van Campen C (2013) Inhaling memories. The Senses and Society 8(2): 133-148.

Vinitzky-Seroussi V and Teeger C (2010) Unpacking the unspoken: Silence in collective memory and forgetting. Social Forces 88(3): 1103-1122.

Wallis C (1899) Skolhygien För Lärare Och Föräldrar. Stockholm: C \& E Gernandts Förlags AB.

Winter B (2016) Taste and smell words form an affectively loaded and emotionally flexible part of the English lexicon. Language, Cognition and Neuroscience 31(8): 975-988.

Yildız C and De Genova N (2018) Un/free mobility: Roma migrants in the European Union. Social Identities 24(4): 425-441.

\section{Author biography}

Alison Gerber is Assistant Professor in the Department of Sociology at Lund University in Sweden. Her research is focused on culture, science and public life, with a special emphasis on the valuation of new kinds of evidence. A book, The Work of Art: Value in Creative Careers, is out now from Stanford University Press. 